\title{
Manajemen Pembelajaran untuk Menciptakan Suasana Belajar Menyenangkan di Masa New Normal
}

\author{
Hasma Nur Jaya ${ }^{1 凶}$, Nurul Idhayani ${ }^{2}$, Nasir $^{3}$ \\ Admistrasi Pendidikan, Universitas Muhammadiyah Kendari(13) \\ Pendidikan Guru Pendidikan Anak Usia Dini, Universitas Muhammadiyah Kendari(2)
}

\begin{abstract}
Abstrak
Tujuan penelitian untuk mengetahui pelaksanaan manajemen pembelajaran dalam menciptakan suasana belajar yang menyenangkan di Taman kanak-kanak Negeri se Kecamatan Ranomeeto Kabupaten Konawe Selatan. Pembelajaran di masa new normal telah menciptakan kultur belajar yang baru bagi anak di PAUD. Oleh karena itu guru diharapkan lebih kreatif menyelenggarakan pembelajaran yang menyenangkan. Jenis penelitian deskriptif kualitatif dengan Informan penelitian 6 orang guru, dan 2 kepala sekolah. Adapun durasi pengumpulan data, dilakukan selama 5 bulan (Mei-September 2020) dengan teknik wawancara, pengamatan, dan dokumentasi. Hasil penelitian menyimpulkan manajemen pembelajaran untuk menciptakan suasana belajar yang menyenangkan dilakukan dalam tiga tahapan, yaitu: perencanaan, pelaksanaan, dan evaluasi. Perencanaan meliputi: menyiapkan skenario pembelajaran, media, dan alat evaluasi, pelaksanaan yaitu implementasi kegiatan yang disesuaikan dengan skenario pembelajaran yang telah dibuat ditahapan sebelumnya, dan evaluasi dilakukan guru secara offline dan online.
\end{abstract}

Katakunci: manajemen pembelajaran; pendidikan anak usia dini; suasana belajar menyenangkan.

\begin{abstract}
The research objective was to determine the implementation of learning management in creating a pleasant learning atmosphere in State Kindergartens in Ranomeeto District, South Konawe Regency. Learning in the new normal era has created a new learning culture for children in PAUD. Therefore, teachers are expected to be more creative in organizing fun learning. This type of qualitative descriptive research with research informants 6 teachers, and 2 principals. The duration of data collection was carried out for 5 months (May September 2020) with interview, observation, and documentation techniques. The results of the study concluded that learning management to create a pleasant learning atmosphere was carried out in three stages, namely: planning, implementation, and evaluation. Planning includes: preparing learning scenarios, media, and evaluation tools, implementation, namely the implementation of activities tailored to the learning scenarios that have been made in the previous stages, and teacher evaluations offline and online.
\end{abstract}

Keywords: learning management; early childhood education programs; the atmosphere was pleasant.

Copyright (c) 2020 Hasma Nur jaya, Nurul Idhayani, Nasir

$\triangle$ Corresponding author:

Email Address : hasmajayanur@gmail.com (Kendari, Indonesia)

Received 24 November 2020, Accepted 6 December 2020, Published 12 December 2020 


\section{PENDAHULUAN}

Hakikatnya pendidikan berfungsi untuk mengembangkan kemampuan, meningkatkan mutu kehidupan, dan martabat manusia baik individu maupun sosial. Dengan kata lain, pendidikan berfungsi sebagai sarana pemberdayaan individudan masyarakat guna menghadapi masa depan. Seperti yang terurai jelas dan tegas pada UU Sisdiknas 2003. Bab II mengenai Dasar, Fungsi, dan Tujuan (Marzuki, 2012).

Saat ini, kebutuhan mendidik orang-orang yang kreatif, berpikiran terbuka, yang mau bekerja dengan orang lain, dan juga yang mengedepankan ide-ide baru, telah memfokuskan perhatian semua orang pada sekolah (Demirci \& Yavaslar, 2018). Dengan kebutuhan tersebut maka peran guru sangat penting dalampendidikan.

Baik buruknya suatu pendidikan dipengaruhi oleh bagaimana seorang guru dapat menyampaikan atau mengajarkan ilmu pengetahuan serta nilai-nilai kehidupan yang mampu membawapeserta didik mewujudkan cita-citanya, baik untuk dirinya, keluarga, masyakarat dan bangsanya (Mursalin et al., 2017). Terkait dengan pentingnya peran seorang guru, maka seyogyanyaguru harus memiliki berbagai kemampuan, tidak hanya kemampuan akademik yang harus dimiliki oleh seorang guru, akan tetapi bagaimana seorang guru mempunyai kemampuan untuk memotivasi peserta didik, agar mau belajar yang nantinya akan meningkatkan prestasi serta cita-cita peserta didik. Lebih spesifiknya lagi peran yang dimaksud disini berkaitan dengan peran guru dalam proses pembelajaran. Guru merupakan faktor penentu yang sangat dominan dalam pendidikan pada umumnya, karena guru memegang peranan dalam proses pembelajaran, dimana proses pembelajaran merupakan inti dari proses pendidikan secara keseluruhan.(Mursalin et al., 2017).

Menurut Maiza \& Nurhafizah (2019) guru merupakan suatu profesi yang sangat mempengaruhi hasil belajar anak didik, kemampuan seorang guru merupakan suatu gambaran yang hakikat dari prilaku guru atau tenaga kependidikan yang akan tampak sangat berarti dan berpengaruh terhadap lingkungan sekitarnya. lembaga pendidikan, hal ini ditentukan oleh keberhasilan pada proses pembelajaran yang dilakukan oleh guru, proses ini pembelajaran sangat penting dilakukan karena dalam rangka mencapai tujuan pembelajaran itu sendiri. Berhasil atau tidaknya proses belajar hal ini ditentukan oleh fungsi dan peran guru yaitu sejauh mana guru dapat menjalankan tugasnya secara profesional serta mampu dalam melaksanakan proses pembelajaran tersebut. Guru merupakan suatu profesi yang sangat mempengaruhi hasil belajar anak didik, guru memiliki satu kesatuan peran dan fungsi yang tak terpisahkan, antara kemampuan mendidik, membimbing, mengajar, dan melatih. Keempat kemampuan tersebut merupakan kemampuan integrativ, yang satu sama lain tak dapat dipisahkan dengan yang lain, Secara terminologis akademis, pengertian mendidik, membimbing, mengajar, dan melatih. (Guru \& Sopian, n.d.).

Guru sangat menentukan keberhasilan peserta didik, terutama dalam kaitannya dengan proses belajar-mengajar, serta merupakan komponen yang paling berpengaruh terhadap terciptanya proses dan hasil pendidikan yang berkualitas sehingga guru dituntut memiliki kompetensi atau kemampuan, berkualitas dan professional (Darwis et al., 2019). Kemampuan professional guru inilah yang dibutuhkan untuk menciptakan kondisi belajar yang menyenangkan dan dapat dicapai jika guru mampu mengatur siswa, sarana pengajaran serta mengendalikannya dalam situasi yang menyenangkan untuk mencapai tujuan pembelajaran. Akan tetapi, apabila terdapat ketidakserasian antara tugas, sarana atau alat, terputusnya keinginan yang satu dengan keinginan yang lain, antara kebutuhan dan pemenuhannya jelas akan terjadi gangguan. Maka menjadi tanggung jawab bersama untuk menciptakan suasana kenyamanan belajar di kelas dan lingkungan sekolah.

Untuk mengetahui tingkat kualitas pembelajaran dalam kegiatan belajar mengajar, perlu diketahui dan dirumuskan indikator-indikator kualitas pembelajaran. Morrison, Mokashi\& Cotter (2011) dalam risetnya telah merumuskan 44 indikator kualitas pembelajaran yang direduksi ke dalam 10 indikator. Kesepuluh indikator kualitas pembelajaran tersebut meliputi: 1) lingkungan fisik mampu menumbuhkan semangatsiswa untuk belajar; 2) iklim 
kelas kondusif untuk belajar; 3) guru menyampaikan pelajaran dengan jelas dan semua siswa mempunyai keinginan untuk berhasil; 4) guru menyampaikan pelajaran secara sistematis dan terfokus; 5) guru menyajikan materi dengan bijaksana; 6) pembelajaran bersifat riil (autentik dengan permasalahan yang dihadapi masyarakat dan siswa); 7) ada penilaian diagnostik yang dilakukan secara periodik; 8) membaca dan menulis sebagai kegiatan yang esensial dalam pembelajaran; 9) menggunakan pertimbangan yang rasional dalam memecahkan masalah; dan 10) menggunakan teknologi pembelajaran, baik untuk mengajar maupun kegiatan belajar siswa(Raharjo \& Yuliana, 2016).

Pembelajaran tidak hanya diartikan sebagai sesuatu yang statis, melainkan suatu konsep yang berkembang sesuai dengan tuntutan kebutuhan hasil pendidikan yang berkaitan dengan kemajuan ilmu dan teknologi yang melekat pada wujud pengembangan kualitas sumber daya manusia (Wahid et al., 2018),untuk itu manajemen kelas menjadi penting seperti yang diungkapkan oleh Koontz dan Weihrich "manajemen merupakan proses mendesain dan memelihara lingkungan, yaitu individu bekerja bersama dalam kelompok, untuk mencapai tujuan-tujuan tertentu secara efisien" (Pratiwi, 2015). Secara historis pada pengelolaan kelas, guru dianggap sebagai Direktur. Penciptaan lingkungan pembelajaran yang efektif melibatkan pengorganisasian kegiatan diruang kelas, pengajaran dan ruang kelas fisik untuk waktu yang efektif, menciptakan lingkungan pembelajaran yang bahagia dan produktif dan meminimalkan gangguan. (Wahid et al., 2018). Apalagi pada kegiatan pembelajaran anak usia dini di PAUD pembelajaran yang berkualitas akan sulit tercapai sebab pembelajaran di PAUD menuntut guru untuk lebih dekat baik secara psikologis juga secara fisik sebab adegan pembelajaran untuk anak usia dini lebih bersifat non formal, dilakukan melalui kegiatan dengan banyak aktivitas bermain dan tidak memiliki target capaian prestasi yang bersifat akademik akan tetapi optimalisasi perkembangansehingga guru dapat menciptakan suasana pembelajaran yang nyaman dan aman bagi anak (Maiza\&Nurhafizah, 2019).

Pendidikan anak usia dini sebagai bagian dari penerapan pendidikan sepanjang hayat (life long education) merupakan portal utama menuju level pendidikan berikutnya. Jika tidak dikawal dengan baik, efeknya dapat berkepanjangan. Selain melalui perencanaan, pengorganisasian, dan pengevaluasian pembelajaran yang baik, para pengelola PAUD hendaknya juga tidak mengesampingkan keberadaan lingkungan sebagai setting pembelajaran (Hidayatulloh, 2014).

Hewi \& Asnawati, (2020) menuliskan dalam sebuah artikel hasil penelitian bahwa berdasarkan permendikbud 2014 Pendidikan anak usia dini sebagai jenjang pendidikan sebelum pendidikan dasarmemberikan layanan pada anak sejak lahir hingga usia enam tahun dengan memberikan stimulasi berupa pemberian rangsangan pendidikan supaya menunjang pertumbuhan dan perkembangan jasmani serta rohani anak sehingga memiliki keterampilan untuk melanjutkan pada jenjang pendidikan selanjutnya yaitu sekolah dasar.

Hasil penelitian lain,guru perlu menciptakan suasana yang menyenangkan agar siswa tidak merasa terbebani. Akan lebih bagus lagi jika guru juga menyampaikan materi dengan metode pembelajaran yang interaktif Pembelajaran Berbasis Peminatan Setiap siswa memiliki minat, bakat, dan kemampuan yang berbeda. Perbedaan tersebut merupakan sunnatullah dan tidak perlu dipertentangkan. Keberagaman tersebut merupakan suatu kekayaan yang tidak ternilai (Mulyati, 2019). Demikian juga penelitian yang dilakukan oleh Wahyuni, (2017) mengungkapkan seorang guruharuslah professional, guru harus mampu menyampaikan materi sealami dan senyaman mungkin bagi siswa, agar siswa tidak frustasi karena tidak segera mengerti tentang apa yang dibahas oleh guru, di sini muncullah joyful and meaningful teaching, Sebuah pembelajaran idealnya menyenangkan dan penuh makna.

Dwi (2020) dalam penelitiannya mengungkapkan aktivitas pembelajaran di masa new normal tentunya menjadi tantangan tersendiri bagi guru taman kanak-kanak. Sebab, ini menjadi hal baru dalam proses pembelajaran dimana segalanya perlu persiapan yang matang 
untuk melaksanakan proses pembelajaran, agar orang tua siswa tidak merasa resah terhadap pendidikan anak. Dengan kemajuan teknologi khususnya internet dan berbagai alatkomunikasi seperti Handphone, Laptop,Smartphone,dan lain sebagainya mampu mempermudah seseorang untuk melakukan berbagai kegiatan sama hal nya dengan proses pembelajaran. Pemaduan penggunaan sumber belajar tradisional (offline) dan online adalah suatu keputusan demokratis untuk menjembatani derasnya arus penyebaan sumber belajar elektronik (e-learning) dan kesulitan melepaskan diri dari pemanfaatan sumber-sumber belajar yang digunakan dalam ruang kelas.

Berdasarkan beberapa pendapat tersebut maka tujuan penelitian ini adalah untuk mengetahui pelaksanaan manajemen pembelajaran dalam menciptakan suasana belajar yang menyenangkan di taman kanak-kanak negeri se kecamatan ranomeeto sebab di kecamatan ranomeeto memiliki potensi sumber daya untuk meningkatkan profesional guru sehingga manajemen dalam menciptakan suasana pembelajaran menjadi hal penting untuk diteliti, banyaknya guru yang memiliki potensi namun tidak berkembang, dan didukung oleh fasilitas yang kompleks.

\section{METODOLOGI}

Penelitian ini menerapkan kaidah pendekatan deskirptif kualitatif. Informan dalam penelitian yaitu: 6 orang guru, dan 2 kepala sekolah. Informan penelitian ditentukan secara purposive sampling. Penelitian dilakukan selama 5 bulan, dimulai Mei sampai dengan September 2020. Sumber data sekunder diperoleh dari data yang tersedia di sekolah, dan sumbersumber lainnya. Untuk dapat memperoleh data secara holistic dan integrative, pengumpulan data dalam penelitian ini menggunakan tiga yaitu;1) Wawancara dengan menggunakan instrumen pedoman wawancara;2) Observasi partisipan (participant observation); dan 3) Studi dokumentasi (studydocument). Analisis data penelitian menggunakan analisis kasus tunggal, yaitu: reduksi data, penyajian, dan penarikan kesimpulan; Adapun tahapan penelitian dapat diihat pada gambar 1.

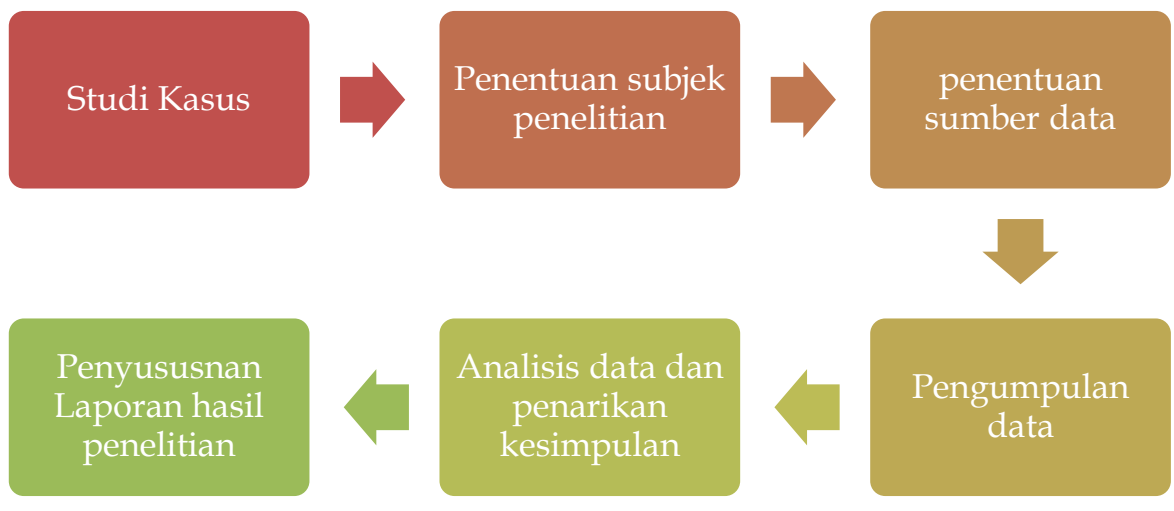

Gambar 1. Tahapan Penelitian

\section{HASIL DAN PEMBAHASAN}

Menciptakan suasana belajar yang menyenangkan merupakan hal penting bagi seorang pendidik, dimana banyak sekolah memilih untuk melakukan tugas mengajar guru secara daring. Kondisi inilah yang menuntut seorang guru harus memiliki keterampilan dalam menciptakan pembelajaran yang menyenangkan dengan suasana pandemi saat ini. DikecamatanRanomeeto Kabupaten Konawe Selatan termaksud daerah zona merah covid 19 sehingga pembelajaran dilakukan secara daring mulai dari tingkat Taman Kanak-Kanak (TK) Hingga tingkat SMA/ sederajat, terdapat 2 Taman kanak-kanak (TK) Negeri dikecamatanranomeeto yaitu TK Negeri pembina Ranomeeto yang beralamat Jln Wolter Mongisidi desa Langgea dengan jumlah guru 13 orang dan kelompok bermain 12 kelas 
masing-masing kelompok terdapat 15 hingga 20 siswa. TK Negeri Wekoila merupakan TK negeri ke dua dikecamatanRanomeeto beralamat di desa amoitoSiama dengan jumlah guru 5 orang dan memiliki 5 kelompok bermain dengan masing-masing kelompok terdapat 10 hingga 18 siswa.

Kegiatan Belajar Mengajar dimasa new normal pada kedua TK Negeri dikecamatanranomeeto tetap dilaksanakan secara daring dan luring. Membuat perencanaan pembelajaran, melaksanakan pembelajaran, dan melakukan evaluasi merupakan kegiatan inti yang dilakukan guru di TK Negeri kecamatan Ranomeeto.

\section{Perencanaan Pembelajaran}

Membuat perencanaan dengan menyusun skenario pembelajaran merupakan hal utama yang dilakukan guru sebelum melaksanakan pembelajaran online maupun offline. Dari data observasi yang diperoleh di TK Negeri se kecamatan ranomeeto guru telah melakukan kegiatan pembelajaran sesuai skenario yang ada. Skenario pembelajaran merupakan urutan cerita yang disusun oleh seorang guru agar suatu kegiatan pembelajaran terselenggara sesuai dengan yang diinginkan (Suningsih, 2018). Gambaran skenario pembelajaran dapat dilihat pada tabel 1 .

Membuat perencanaan dengan menyusun perangkat pembelajaran merupakan hal utama yang dilakukan guru sebelum melaksanakan pembelajaran daring maupun luring. Berdasarkan Hasil Wawancara dengan kepala sekolah TK Negeri Pembina terkait perencanaan Kelas Pembelajaran menyatakan bahwa: "Sebelum melaksanakan Pembelajaran guru harus mempersiapkan beberapa hal yaitu RKH, Media Daring seperti Whattshap group, link youtobe, link ruang guru, serta media lain yang dapat dijadikan sumber belajar anak, serta absen anak. (Nusiatin, S.Pd. 19 September 2020).

Pernyataan diatas sejalan dengan hasil wawancara peneliti dengan salah seorang guru yang bersedia untuk diwawancarai menyatakan bahwa: "Setiap guru di TK Negeri Pembina tetap melaksanakan pembelajaran dengan melakukan persiapan membuat $R K H$, merancang sistem pembelajaran daring dengan memilih media yang disepakati bersama wali murid". (Sitti, S.Pd, 20 September 2020).

Hal yang sama juga dinyatakan oleh guru lain yang kebetulan saat peneliti turun lapangan berada disekolah mengatakan bahwa: "Kegiatan Pembelajaran tetap dilaksanakan walaupun secara daring, namun untuk kelas saya ada beberapa anak yang tidak bisa melakukan pembelajaran daring sebab keterbatasan ekonomi sehingga sebagai guru membuat perencanaan pengaran luring juga tetap dilakukan agar anak-anak tetap memiliki kegiatan dan memperoleh pegalaman belajar di taman kanak-kanak" (Decy Cristina, S.Pd, 19 September 2020).

Berdasarkan pernyataan hasil wawancara bersama guru dan kepala sekolah di Tk negeri Pembina diperoleh data bahwa sekenario pembelajaran disusun dengan langkahlangkah Guru mempelajari alat evaluasi yang digunakan untuk peserta didik guna mengetahui materi apa yang akan dipelajari dan dengan cara bagaimana guru akan memfasilitasi peserta didik, guru menulis langkah-langkah yang akan dilakukan dalam proses pembelajaran, sesuai dengan tahapan-tahapan pembelajaran yang direncanakan, guru menuliskan rencana penilaian terhadap kagiatan belajar peserta didik.

Hasil penelitian yang diperoleh di TK Negeri Wekoila diperoleh data selain penyusunan Skenario pembelajaran menjadi hal penting sebab penyusunan skenario pembelajaran menjadikan guru mudah dalam melaksanakan proses belajar mengajar di dalam kelas, dengan scenario tersebut guru telah memikirkan metode mengajar yang menjadikan suasana lebih menyenangkan. Kegiatan menciptakan pembelajaran menyenangkan dilakukan untuk mendukung terlaksananya program pengajaran yang berkualitas. Pada penelitian Hewi \& Asnawati, (2020) mengungkapkan tugas perencanaan pendidik anak usia dini berhubungan dengan penyusunan rencana pembelajaran harian dan mingguan serta rencana pembelajaran semester, sementara pelaksanaan pembelajaran dilakukan melalui kegiatan 
Manajemen Pembelajaran untuk Menciptakan Suasana Belajar Menyenangkan dimasa New Normal

DOI: $10.31004 /$ obsesi.v5i2.911

bermain dan penilaian hasil pembelajaran dilakukan untuk melihat capaian aspek perkembangan anak usia dini setelah dilakukan pembelajaran

Tabel 1. Skenario Pembelajaran

\begin{tabular}{|c|c|}
\hline Skenario Kegiatan & Aktivitas \\
\hline Kegiatan Guru & $\begin{array}{l}\text { - } \text { Guru membuka pembelajaran dengan mengucapkan salam dan membaca doa sebelum } \\
\text { - } \text { - Guru menyampaikan tujuan pembelajaran } \\
\text { - } \text { Guru menyampaikan langkah-langkah pembelajaran } \\
\text { - Guru memotivasi anak-anak untuk belajar } \\
\text { - } \text { Guru mengatur posisi duduk anak } \\
\text { - GuruMemperkenalkan media yang digunakan dalam pembelajaran } \\
\text { - Guru menstimulasi anak melalui pertanyaan sambil bernyayi } \\
\text { - Guru memberi kesempatan pada anak untuk menggunakan media yang telah } \\
\text { - } \text { ditentukan sesuai tema pembelajaran }\end{array}$ \\
\hline Kegiatan Anak & $\begin{array}{l}\text { - Memperhatikan apa yang disampaikan guru dan berdoa sebelum melakkan kegiatan } \\
\text { - } \text { Mengunakan media pembelajaran yang sesui dengan tema pembelajaran } \\
\text { - } \text { Anak mampu menggunakan media yang telah dipilih dengan mandiri } \\
\text { - } \text { Perhatian anak tertuju pada guru } \\
\text { - Anak mampu menyelesaikan kegiatan pembelajaran sesuai dengan waktu yang } \\
\text { diberikan guru } \\
\text { - Anak mampu dengan mudah berkonsentrasi pada kegiatan yang dilakukan } \\
\text { - Anak mampu menumbuhkan kepercayaan diri pada saat proses pembelajaran } \\
\text { - Anak dengan percaya diri memperlihatkan hasil pekerjaannya }\end{array}$ \\
\hline $\begin{array}{l}\text { Kegiatan } \\
\text { Pembelajaran }\end{array}$ & $\begin{array}{ll}\text { - } & \text { Membuka pembelajaran dengan mengucapkan salam dan membaca doa sebelum } \\
& \text { belajar } \\
\text { - } & \text { Menyampaikan tujuan pembelajaran } \\
\text { - } & \text { Menyampaikan langkah-langkah pembelajaran } \\
\text { - } & \text { Memotivasi anak-anak untuk belajar } \\
\text { - } & \text { Mengatur posisi duduk anak } \\
\text { - } & \text { Memperkenalkan media yang digunakan dalam pembelajaran } \\
\text { - } & \text { Menstimulasi anak melalui pertanyaan } \\
\text { - } & \text { Memberi kesempatan pada anak untuk menggunakan media yang telah ditentukan } \\
\text { - } & \text { sesuai tema pembelajaran } \\
\end{array}$ \\
\hline
\end{tabular}

Sumber: TK Negeri Pembina Kecamatan ranomeeto

Selain itu temuan dalam penelitian ini menunjukkan bahwa dengan perencanaan skenario pembelajaran yang matang dapat meningkatkan kepercayaan diri seorang guru dalam pembelajaran serta memberikan motivasi kepada peserta didik untuk mengikuti Proses Belajar Mengajar walaupun dilakukan secara online. Temuan ini sejalan dengan tulisan Pernantah, (2019) mengungkapkan bahwa Keterampilan menyiapkan skenario pembelajaran adalah suatu keterampilan dalam mendesain atau merancang langkah- langkah kegiatan pembelajaran (pendahuluan, inti, penutup), dan memilih (metode, media, pendekatan) yang tepat dan sesuai. Semua hal itu dilakukan agar guru maupun peserta didik mudah menjalankan dan memahami proses pembelajarannya

\section{Pelaksanaan}

Pelaksanaan manajemen kelas yang efektif dalam pembelajaran mampu mewujudkan kondisi kelas sebagai lingkungan pembelajaran yang memungkinkan siswa untuk mengembangkan kemampuan seoptimal mungkin, menghilangkan berbagai hambatan yang dapat menghalangi interaksi pembelajaran yang mendukung dan memungkinkan siswa belajar sesuai dengan lingkugan sosial, emosional dan intelektual siswa, serta dapat membina dan membimbing siswa sesuai dengan latar sosial, ekonomi, budaya dan sifat/karakter siswa yang berbeda. 
Dimasanew normal saat ini pelaksanaan pembelajaran sangat memerlukan keahlian seorang guru dalam melakukan pengelolaan pembelajaran agar minat belajar peserta didik dapat meningkat dan menyenangkan. Penelitian Pada TK Negeri se-kecamatan ranomeeto diperoleh data bahwa metode yang digunakan guru dalam proses belajar mengajar dilakukan secara online dan offline oleh sebab itu untuk menciptakan suasana belajar yang menyenangkan perlu mempersiapkan pemecahan masalah yang cenderung terjadi saat proses pembelajaran misalnya beberapa orang tua maupun peserta didik tidak menerima proses pembelajaran yang diterapkan guru. Tindakan tersebut dapat berupa pencegahan yaitu dengan jalan menyediakan kondisi baik secara fisik maupun kondisi sosio-emosional sehingga rasa aman dan nyaman untuk belajar dirasakan oleh peserta didik.
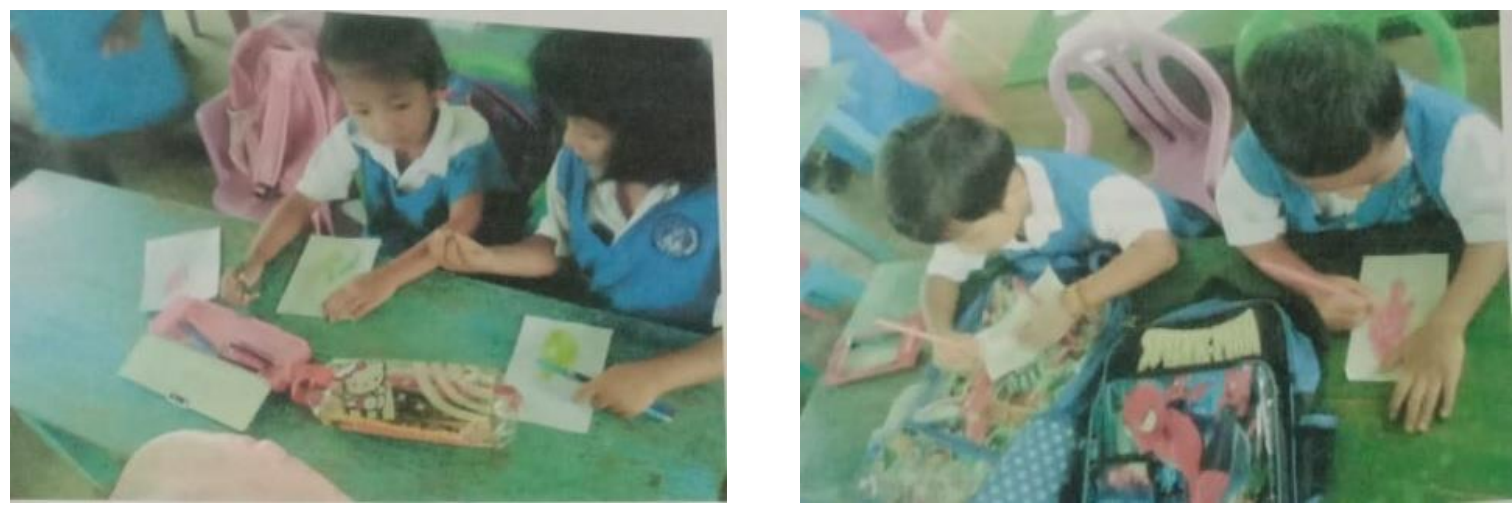

Gambar 2. Suasana Belajar Secara Offline

Gambar 2 menunjukkan siswa sedang melaksanakan pembelajaran secara offline yang jadwalnya telah ditentukan dalam skenario pembelajaran,peserta didik yang mengikuti pembelajaran offline wajib mengikuti aturan yang telah disampaikan sebelumnya oleh guru. Jumlah peserta didik yang mengikuti pembelajaran offline pun dibatasi oleh guru dalam sehari guru hanya bisa mengajar 5-6 siswa saja, dengan menerapkan aturan sistem gilir kehadiran menyebabkan masalah pada kondisi psikologis siswa yaitu kurangnya semangat belajar disebabkan peserta didik merasa sepi dan tidak dapat bermain secara bebas dengan kawannya hal ini menuntut guru untuk berperan aktif dan memahami kondisi psikologis siswa.

Selain itu Hasil penelitian yang dilakukan di TK sekecamatan ranomeeto diperoleh data bahwa untuk menciptakan suasana belajar yang menyenangkan guru perlu memahami masalah yang dihadapi peserta didik salah satunya perubahan tingkah laku dimana Salah satu cara yang dilakukan guru dalam pengendalian tingkah laku peserta didik adalah dengan membangkitkan minat belajar untuk pembentukan karakter-karakter peserta didik antara lain, menyediakan media belajar agar peserta didik tertarik mengikuti pembelajaran, memberikan suasana yang menyenangkan misalnya memilih pakaian yang berbeda dengan biasanya saat mengikuti pembelajaran daring, memberikan tugas yang tidak menyusahkan peserta didik dan selalu memberikan kata-kata motivasi diakhir pembelajaran serta Pendekatan pribadi secara intens dan kontinu selalu saya lakukan untuk mengetahui karakter dan kondisi peserta didik dalam mengikuti pembelajaran dengan harapan peserta didik tetap bersemangat untuk terus belajar dan menyelesaikan tugas yang diberikan.

Menurut Miftahudin (2010) pendidikan karakter pada usia dini di keluarga bertujuan untuk pembentukan, pada usia remaja di sekolah bertujuan untuk pengembangan, sedangkan pada usia dewasa di bangku kuliah bertujuan untuk pemantapan. Tugas-tugas pendidik adalah menyediakan lingkungan belajar yang baik untuk membentuk, mengembangkan, dan memantapkan karakter peserta didiknya.(Cahyaningrum et al., 2017) 
Selain pendekatan kepada peserta didik lingkungan fisik merupakan salah satu faktor yang mempengaruhi kondisi belajar siswa misalnya ruang belajar, metode pembelajaran serta media yang digunakan.

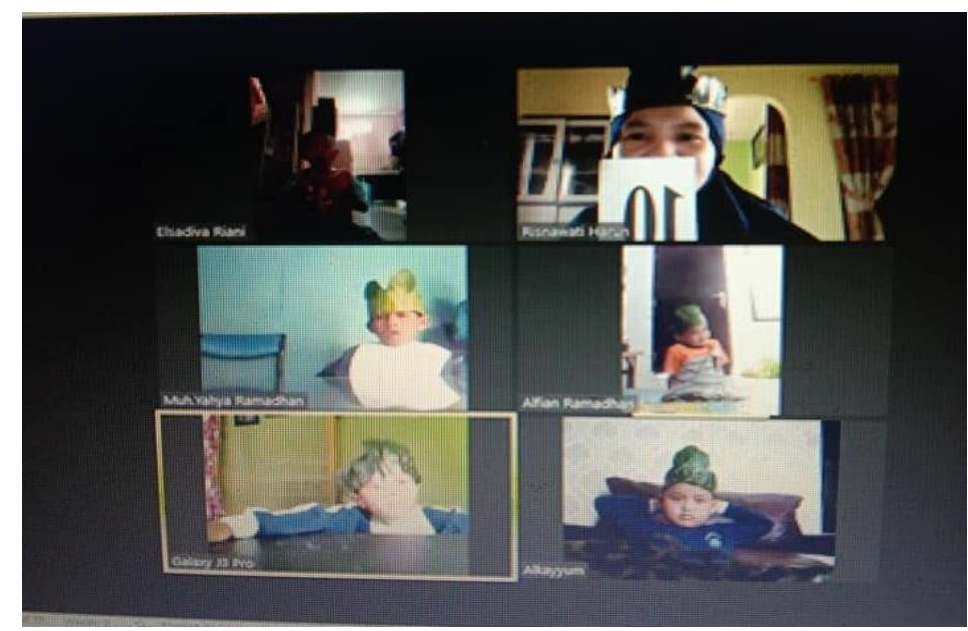

Gambar 3. Suasana Pembelajaran Secara Online

Gambar 3 menunjukkan kegiatan pembelajaran yang dilakukan guru secara online yang dilakukan dari rumah. Hasil wawancara bersama kepala sekolah dan guru diperoleh kesimpulan bahwa Rumah sebagai ruang belajar yang digunakan peserta didik untuk melakukan proses belajar mengajar sangat mempengaruhi kondisi belajar sebab peserta didik diusia Taman kanak-kanak masih sangat memerlukan suasana yang bebas dalam belajar namun karena tuntutan keadaan membuat mereka harus belajar dirumah, metode yang digunakan gurupun terkadang membuat peserta didik merasa bosan sebab setiap harinya guru harus melakukan pembelajaran menggunakan virtual meeting dan medianya pun disiapkan oleh peserta didik sehingga membuat mereka cenderung kelelahan namun hal tersebut dapat diatasi oleh peserta didik selain itu pelaksanaan pembelajaran ini dapat meraih minat anak dalam penggunaan metode dan media, karena pada umumnya usia dini senang dengan pembelajaran yang menyenangkan dan variatif. Kesiapan guru untuk memberikan pemahaman kepada siswa dengan keterampilan penjelasan yang mudah dipahami oleh peserta didik juga menjadi point penting untuk keberhasilan menciptakan suasana yang menyenangkan sebab jika guru memberikan penjelasan yang membosankan maka peserta didik cenderung pasif dan tidak memiliki antusias dalam mengikuti pembelajaran. Hasil penelitian tersebut sejalan dengan yang diungkapkan Bastian, 2019 Menjelaskan merupakan suatu aspek penting yang harus dimiliki guru, mengingat sebagian besar pembelajaran menuntut guru untuk memberikan penjelasan. Oleh sebab itu, keterampilan menjelaskan perlu ditingkatkan agar dapat mencapai hasil yang optimal.

Anak memiliki cara dan tipologi belajar yang berbeda-beda. Oleh karena itu, pemilihan model dan media pembelajaran sangat menentukan pembelajaran yang telah berlangsung berhasil atau tidak. Berdasarkan pemikiran Ula (2013) cara seseorang menyerap informasi kemudian mengolahnya serta memanifestasikan dalam wujud nyata perilaku hidupnya. Seorang guru yang memahami karakter dan tipe belajar anak didiknya tentu akan memilih media yang bukan hanya mempermudahnya dalam mengajar, tetapi juga membantu anak didiknya memahami pelajaran yang diberikan. (Sary, 2018).

Selain itu optimalisasi pemanfaatan media pembelajaran dapat mempertinggi kualitas proses dan hasil belajar siswa hal ini terjadi karena: a) penggunaan media dalam kegiatan pembelajaran lebih menarik perhatian siswa sehingga dapat menumbuhkan motivasi belajar; b) bahan pembelajaran lebih jelas maknanya sehingga dapat lebih dipahami oleh siswa; c) metode mengajar lebih bervariasi, namun juga komunikasi verbal melalui penuturan kata- 
kata oleh guru, sehingga siswa tidak bosan; d) siswa lebih banyak melakukan kegiatan belajar, karena tidak hanya mendengarkan uraian guru, tetapi juga aktivitas lain seperti mengamati, melakukan, mendemonstrasikan dan lain-lain (Raharjo \& Yuliana, 2016).

Temuan dari penelitian pelaksanaan pembelajaran dalam menciptakan suasana belajar yang menyenangkan di TK Negeri sekecamatan Ranomeetoini diperoleh fakta bahwaSuatu pembelajaran dapat dikatakan efektif apabila terjadi interaksi yang baik antara guru dan peserta didik dengan tujuan pembelajaran yang menyenangkan. Interaksi yang baik adalah interaksi yang tidak hanya terjadi didalam kelas secara langsung akan tetapi juga terjadi diluar kelas seperti rumah yang keduanya dapat meningkatkan motivasi belajar siswa.

Hal senada juga diungkapkanDwi, $d k k_{.}$, (2020)efektif atau tidaknya pembelajaran dapat diidentifikasi melalui perilaku-perilaku antara pemelajar dan pembelajar. Bagaimana respon pembelajar terhadap apa yang disampaikan oleh pemelajar. Namun disisi lain pembelajaran yang efektif yang ditunjukkan dengan adanya kemauan anak dalam mentaati peraturan sekolah, terciptanya suasana pembelajaran yang kondusif dalam proses belajar mengajar, penyampaian informasi, perencanaan kegiatan harian yang matang, metode pembelajaran, waktu yang digunakan dalam pembelajaran, penanaman nilai-nilai agama, pemanfaatan fasilitas dan penca- paian kesuksesan dalam pembelajaran (Rohmawati, 2015).

\section{Evaluasi Pembelajaran yang Menyenangkan}

Setelah melakukan kegiatan pembelajaran evaluasi dibutuhkan untuk mengetahui keberhasilan atau ketercapaian tujuan pembelajaran yang ditatapkan. Evaluasi belajar merupakan cerminan kemampuan siswa dalam mengatasi suatu mata pelajaran, evaluasi tidak hanya tercermin pada nilai akan tetapi penguasaan konsep yang jauh lebih bermakna. Evaluasi pembelajaran biasanya dilaksanakan dengan cara menyelenggarakan hasil belajar siswa meliputi: ulangan harian dan ulangan umum. Guru bukan hanya mengetahui kompetensi peserta didik setelah pembelajaran dan pembentukan kompetensi tetapi harus pula mengetahui perubahan kemajuan perilaku peserta didik.

Berdasarkan hasil wawancara bersama Kepala Sekolah dan guru taman kanak-kanak dikecamatanranomeeto diperoleh data bahwa hasil evaluasi pembelajaran peserta didik yang telah dilakukan dibulan juni 2020 mengalami penurunan kompetensi dan kemajuan perilaku, ini disebabkan Pada saat melakukan evaluasi pembelajaran terdapat beberapa tahapan yang harus dipersiapkan guru yaitu saat pelajaran telah usia atau setiap harinya guru memberikan evaluasi dan evaluasi yang diberikan saat akhir semester, walaupun evaluasi tidak diberikan secara offline namun guru tetap bisa melakukan evaluasi secara online tetapi ada juga beberapa siswa meminta evaluasi secara offline dengan membuat jadwal bergilir disekolah sehingga hasil Evaluasi yang diberikan guru kepada peserta didik secara online memiliki nilai yang cenderung rendah atau berpredikat BM (Belum Berkembang) sedangkan anak yang diberikan evaluasi secara offline memiliki nilai yang cukup baik dengan predikat BSB (Berkembang Sangat Baik) Walaupun masih ada juga yang nilainya MB (Mulai Berkembang). Menurut Rohita \& Nurfadilah, 2018 untuk melakukan penilaian perlu melihat tingkat pencapaian perkembangan tersebut meliputi seluruh aspek perkembangan anak, yaitu perkembangan moral agama, perkembangan sosial emosional, perkembangan bahasa, perkembangan fisik motorik, perkembangan kognitif, dan perkembangan seni. Keenam aspek perkembangan tersebut harus dapat dinilai untuk mengetahui tingkat pencapaian yang dimiliki anak berdasarkan indikator-indikator yang ada. Hal senada juga diungkapkan oleh Agustin et al.,(2020) kegiatan penilaian perkembangan anak dapat dijadikan sebagai salah satu cara membantu pendidik dalam memantau proses, kemajuan, dan perbaikan pembelajaran anak secara berkesinambungan sehingga dapat memberikan umpan balik bagi pendidik dalam menyempurnakan proses dan produk pembelajaran.

Tabel 2 merupakan lembar penilaian yang di siapkan guru sebelum melaksanakan pembelajaran. 
Tabel 2. Lembar Penilaian

\begin{tabular}{|c|c|c|c|c|c|}
\hline \multirow{2}{*}{ Aspek } & \multirow{2}{*}{ Indikator } & \multicolumn{4}{|c|}{ Nama anak } \\
\hline & & BSB & BSH & MB & BB \\
\hline Kelancaran & $\begin{array}{l}\text { Kelancaran anak dalam menuangkan ide-idenya } \\
\text { dalam kegiatan pembelajaran } \\
\text { Anak mampu menuangkan imajinasi pada }\end{array}$ & & & & \\
\hline Keluwesan & kegiatan pembelajaran & & & & \\
\hline Keaslian & Anak dapat menggunakan media pembelajaran & & & & \\
\hline Elaborasi & $\begin{array}{l}\text { Anak mampu menceritakan hasil kegiatan yang } \\
\text { telah dilakukan }\end{array}$ & & & & \\
\hline Keuletan & $\begin{array}{l}\text { Anak mampu melakukan kegiatan sesuai } \\
\text { petunjuk guru }\end{array}$ & & & & \\
\hline Kesabaran & Anak sabar mengikuti pembelajaran hingga akhir & & & & \\
\hline
\end{tabular}

Sumber: TK Negeri Pembina Ranomeeto

Dari tabel 2 diperoleh data bahwa tidak terjadi perbedaan antara lembar penilaian yang dipersiapkan guru untuk peserta didik yang melakukan pembelajaran online maupun offline. Salah seorang guru mengatakan bahwa lembar penilaian diberikan sama kepada seluruh peserta didik baik yang melaksanakan ujian secara online maupun offline, hal ini dilakukan untuk menjaga objektifitas dalam melakukan penilaian. Seperti yang diungkapkan oleh Santrock Penilaian dikatakan adil apabila semua siswa mendapatkan kesempatan yang sama untuk belajar dan menunjukkan kemampuan serta menilai kemampuan mereka secara objektif (Gomes, 2019).

Temuan pada penelitian ini terdapat pada evaluasi pembelajaran dimana hasil penilaian yang dilakukan guru belum menunjukkan objektifitas disebabkan lembar penilaian yang diberikan tidak memiliki perbedaan antara peserta didik yang melaksanakan ujian secara offline dengan online hal ini dianggap merugikan peserta didik yang melaksanakan ujian secara offline sebab pada beberapa aspek penilaian peserta didik melakukannya secara mandiri menyebabkan mereka memperoleh nilai MB bahkan ada yang BSH sedangkan peserta didik online memperoleh nilai $\mathrm{MB}$ bahkan $\mathrm{BB}$ hal ini disebabkan peserta didik seringkali mendapat bantuan keluarga dalam menyelesaikan soal evaluasi.

\section{SIMPULAN}

Peneliti menyimpulkan bahwa manajemen pembelajaran untuk menciptakan suasana belajar yang menyenangkan diawali dengan perencanaan yaitu menyiapkan skenario pembelajaran, media, dan alat evaluasi, dan pelaksanaan pembelajaran dibutuhkan media yang sesuai dengan kondisi siswa. Kegiatan evaluasi yang dilaksanakan guru belum dilakukan secara objektif sebab lembar penilaian ujian offline tidak memiliki perbedaan dengan ujian yang dilaksanakan secara online sehingga hasil yang diperoleh peserta didik cenderung lebih baik jika dilaksanakan secara online karena peserta didik tidak mengerjakan evaluasi secara mandiri.

\section{UCAPAN TERIMA KASIH}

Peneliti mengucapkan terima kasih kepada seluruh pihak yang telah membantu peneliti. dimulai dari tahapan persiapan, hingga penyelesaian penelitian, terkhusus kepada DRPM yang mendanai penelitian ini, LPPM Universitas Muhammadiyah Kendari, dan para informan (Kepala sekolah dan guru TK Negeri se- Kecamatan Ranomeeto)

\section{DAFTAR PUSTAKA}

Agustin, M., Puspita, R. D., Nurinten, D., \& Nafiqoh, H. (2020). Tipikal Kendala Guru PAUD dalam Mengajar pada Masa Pandemi Covid 19 dan Implikasinya. Jurnal Obsesi : Jurnal Pendidikan Anak Usia Dini, 5(1), 334. https:/ / doi.org/10.31004/obsesi.v5i1.598 
Bastian, B. (2019). Analisis Keterampilan Dasar Mengajar Guru Dalam Melaksanakan Pembelajaran Di Sekolah Dasar. JURNAL PAJAR (Pendidikan Dan Pengajaran), 3(6), 1357. https://doi.org/10.33578/ pjr.v3i6.7899

Cahyaningrum, E. S., Sudaryanti, S., \& Purwanto, N. A. (2017). Pengembangan Nilai-Nilai Karakter Anak Usia Dini Melalui Pembiasaan Dan Keteladanan. Jurnal Pendidikan Anak, 6(2), 203-213. https:/ / doi.org/10.21831/jpa.v6i2.17707

Darwis, M., Batari, U. D., Salam, R., Kasmita, M., \& Baharuddin, A. (2019). Pengaruh Kompetensi Profesional Guru Terhadap Kualitas Proses Pembelajaran Pada Paket Keahlian Administrasi Perkantoran Di SMK Negeri 1 Gowa. Jurnal Ad'ministrare, 5(2), 105. https://doi.org/10.26858/ja.v5i2.7889

Demirci, C., \& Yavaslar, E. (2018). Active learning: Let's make them a song. Cypriot Journal of Educational Sciences, 13(3), 288-298. https://doi.org/10.18844/cjes.v13i3.3199

Dwi, B., Amelia, A., Hasanah, U., \& Putra, A. M. (2020). Analisis Keefektifan Pembelajaran Online di Masa Pandemi Covid-19. Jurnal Pendidikan Guru Sekolah Dasar, 2(1), 3.

Gomes, F. De. (2019). Analisis Kesulitan Guru Paud Dalam Menilai. JURNAL Pendidikan Dan Kebudayaan Missio, 11(2 Juli), 293-305.

Guru, D. A. N. F., \& Sopian, A. (n.d.). Tugas, peran, dan fungsi guru dalam pendidikan. c, 88-97.

Hewi, L., \& Asnawati, L. (2020). Strategi Pendidik Anak Usia Dini Era Covid-19 dalam Menumbuhkan Kemampuan Berfikir Logis. Jurnal Obsesi : Jurnal Pendidikan Anak Usia Dini, 5(1), 158. https://doi.org/10.31004/obsesi.v5i1.530

Hidayatulloh, M. A. (2014). Lingkungan Menyenangkan dalam Pendidikan Anak Usia Dini : Pemikiran Montessori. Nadwa | Jurnal Pendidikan Islam, 8(April).

Maiza, Z., \& Nurhafizah, N. (2019). Pengembangan Keprofesian Berkelanjutan dalam Meningkatkan Profesionalisme Guru Pendidikan Anak Usia Dini. Jurnal Obsesi : Jurnal Pendidikan Anak Usia Dini, 3(2), 356. https:/ / doi.org/10.31004/obsesi.v3i2.196

Marzuki. (2012). Politik Pendidikan Nasional dalam Bingkai Undang-undang Sistem Pendidikan Nasional. Jurnal Penelitian Humaniora, 17(2), 16-38.

Mulyati, M. (2019). Alim | Journal of Islamic Educatioan. I(2), 389-400.

Mursalin, Sulaiman, \& Nurmasyitah. (2017). Peran Guru Dalam Pelaksanaan Manajemen Kelas Di Gugus Bungong Seulangakecamatan Syiah Kualakota Banda Aceh. Jurnal Ilmiah Pendidikan Guru Sekolah Dasar, 2(1), 105-114.

Pernantah, P. S. (2019). Desain Skenario Pembelajaran Aktif Dengan Metode "Mikir" Pada Mata Kuliah Pendidikan IPS. Indonesian Journal of Social Science Education (IJSSE), 1(2), 145-155.

Pratiwi, Z. M. E. (2015). Institut Agama Islam Negeri. 57168.

Raharjo, S. B., \& Yuliana, L. (2016). Manajemen Sekolah Untuk Mencapai Sekolah Unggul Yang Menyenangkan: Studi Kasus Di Sman 1 Sleman Yogyakarta. Jurnal Pendidikan Dan Kebudayaan, 1(2), 203. https:/ / doi.org/10.24832/jpnk.v1i2.769

Rohita, R., \& Nurfadilah, N. (2018). Pelaksanaan Penilaian Pembelajaran di Taman KanakKanak (Studi Deskriptif pada Taman Kanak-kanak di Jakarta). Jurnal Al-Azhar Indonesia Seri Humaniora, 4(1), 53. https:// doi.org/10.36722/sh.v4i1.255

Rohmawati, A. (2015). Usia Taman Kanak-kanak. Jurnal Pendidikan Usia Dini, 9(1), 15-32.

Sary, Y. N. E. (2018). Relationship of Parenting with Child Interpersonal Intelligence in Wonokerto Village, Lumajang Regency. Jurnal Obsesi : Jurnal Pendidikan Anak Usia Dini, 2(2), 137. https:// doi.org/10.31004/obsesi.v2i2.93

Suningsih, A. (2018). Mengapa Skenario Pembelajaran Perlu Pendidikan Karakter? International Journal of Community Service Learning, 2(1), 34. https:// doi.org/10.23887/ijcsl.v2i1.12889

Wahid, A. H., Muali, C., \& Mutmainnah, M. (2018). Manajemen Kelas Dalam Menciptakan Suasana Belajar Yang Kondusif; Upaya Peningkatan Prestasi Belajar Siswa. Al-Fikrah: Jurnal Manajemen Pendidikan, 5(2), 179. https://doi.org/10.31958/jaf.v5i2.1106

Wahyuni, R. (2017). No. BMC Public Health, 5(1), 1-8. 